\title{
RENAL FUNCTION, WATER, ELECTROLYTES AND OEDEMA IN PREGNANCY
}

\author{
A. D. Telford Govan, M.B.(Glas.), F.R.C.P.(Edin.), F.R.C.O.G. \\ Director of Research, Glasgow Royal Maternity Hospitals \\ The Research Department, Glasgow Royal Maternity and Women's Hospital, Rottenrow, Glasgow
}

For several decades now the problem of kidney function in pregnancy has fascinated observers, particularly in relation to the occurrence of pre-eclampsia. The central position of the kidney in this condition, early considered as a renal disease, has been almost proselytized in recent years. At the same time the apparently inexplicable changes in salt and water metabolism have resulted in an enormous literature. The present writer makes no claim to provide an answer to these problems but rather to review the more important statements in the literature, bring certain facts into apposition, draw tentative if perhaps wrong conclusions and hope that by doing so, someone else may see light and produce a complete solution.

There are many factors which influence the composition of the urine and function of the kidneys in pregnancy. It is still to some extent a mystery how the kidney manages to deal with the products of metabolism and at the same time regulate the output of fluid and solutes in such a way as to allow for the continued growth of the conceptus and expansion of the circulatory space.

As a starting point one may consider a normal pregnancy of say 28 weeks. In such a patient the blood volume might have increased by $20 \%$ (Dieckmann and Wegner; 1934; Albers, 1939; Mull and Bill, I945; Adams, 1954) and the cardiac output would have reached its maximum, being approximately one-third greater than in the non-pregnant (Hamilton, I949; Adams, I954). The renal plasma flow is therefore greatly increased (Bucht and Werkö, 1953; Sims and Krantz, 1959) from $500 \mathrm{ml} . / \mathrm{min}$. to 700 or $800 \mathrm{ml} . / \mathrm{min}$. Similarly, although varying figures are reported in the literature most observers are agreed that the glomerular filtration rate (GFR) is increased from approximately $110-120 \mathrm{ml} . / \mathrm{min}$. perhaps to as much as $150-180 \mathrm{ml} / \mathrm{min}$. (Bucht and Werkö, 1953; Sims and Krantz, I959; Page, I957; Aubert, Charvet and Creyssel, 1955). This means in effect that up to roo extra litres of fluid may pass into the renal tubules each day. Assuming that the intake of fluid is within normal limits, the pregnant woman would very quickly lose fluid and solutes and the body fluid volume be brought back to non-pregnant levels, or eveno below, if tubular reabsorption were unchanged.

As it is there is a slight diminution in the amount of urine excreted per day, and a reduction in the amount of many of the solutes.

It is apparent from these investigations that the renal tubules must make functional adjustments $\vec{\perp}$ to cope with the increase in glomerular filtrate.o Chesley (1943) has calculated that the total gain in extracellular water during pregnancy may amount to 6.3. 1. MacGillivray (1960) using 'heavy‥ water' techniques puts the figure at 7.41 . and $\overrightarrow{-}$ showed that water increased by $6.3 \%$ of the bodyo weight. McCartney, Pottinger and Harred(1959) using similar techniques showed that to ilo body water increased by $6.5 \%$ of the 'lean tissưe mass'.

\section{Control of Urine Volume}

Abundant evidence exists to show that certain $\underset{\vec{O}}{\vec{B}}$ forms of renal tubular activity are altered during 3 pregnancy. The question of water excretion is intriguing. Reports by several investigators (Dieckmann, I94Ib) suggest that there is ano increased reabsorption of fluid by the tubules: Theobald (1934, 1946) states that water-diuresis $\frac{\sigma}{3}$ curves show that pregnant women are incapable of secreting urine at more than half the normalo non-pregnant rate. Some modification of this statement must be made. If it were true one ? might expect all pregnant women to become $>$ progressively odematous. Several points are to be noted in assessing the results of these tests. $N$ Smirk (r933a, b, c) has shown that approximately one-third of ingested water is distributed to the lower limbs and if the venous pressure in these is $\omega$ raised, the fluid becomes trapped (Baldes and Smirk, 1934). This can be seen in normal pregnant patients. Towards the end of pregnancy it is common to find patients complaining of swelling ${ }_{+}^{+}$ of the feet at the end of the day; this is found in $\frac{0}{0}$ $66 \%$ of all patients (Dexter and Weiss, 194I). The explanation is to be found in the increased $\frac{\rho}{\odot}$ 
venous pressure in the lower half of the body produced by the pressure of the enlarged uterus on the veins, and by the influence of the arteriovenous fistula in the placenta. Almost all of the water-excretion tests reported have been carried out in one of two ways. Either a straightforward water-diuresis test has been performed with the patient in the dorsal position, which does nothing to relieve the venous pressure, or conclusions as to water excretion have been drawn from tests performed using solutions of sodium chloride. Janney and Walker (1932) and Walker, McManus and Janney (1933) compared excretion after a water load in non-pregnant normal patients with that in normal pregnant patients. In pregnancy the patient only excreted $55 \%$ if kept in the dorsal position, $32 \%$ if in a sitting position but $99 \%$ if turned on her side. In other words there is no evidence to indicate that there is any specific alteration in the handling of water by the kidney in normal pregnancy.

\section{Sodium Metabolism}

The position with regard to sodium metabolism is much more confused. The earlier literature seemed to indicate that an enormous retention of salt occurred in normal pregnancy (Coons, Coons and Schiefelbusch, 1934). Reported estimates of sodium retention vary from $4.8 \mathrm{mEq}$. to $55 \mathrm{mEq}$. per 24 hours, and of potassium from $0.26 \mathrm{mEq}$. to $36.5 \mathrm{mEq}$. per 24 hours. Hummel, Hunscher, Bates, Bonner and Macy (1937) in a balance study extending over 145 days found a retention of $207 \mathrm{~g}$. potassium and 81 g. of sodium. Chesley (1944) summarised the findings of authors in the literature prior to r944. These all showed a remarkable retention of sodium varying from $\mathrm{I} .6$ to $8.8 \mathrm{~g}$. per week, which, if it were osmotically active, would lead to enormous water retention.

More recent studies have questioned the validity of these statements. Chesley, Valenti and Uichanco (1959) studied the output of water and sodium in the early puerperium. On the basis of their findings they came to the conclusion that pregnancy is not accompanied by any significant hydration of the tissues or by storage of osmotically active sodium. McCartney, Pottinger and Harrod (1959) demonstrated that the percentage of total body water did not alter during pregnancy, and the exchangeable sodium in terms of $\mathrm{mEq} . / \mathrm{Kg}$. bodyweight was somewhat reduced. Plentl and Gray (r959) calculated that the increase in total sodium could be accounted for by the products of gestation and increase in blood volume. MacGillivray (1960) in careful experiments with deuterium oxide and radio-active cations proved that although there is an absolute increase in exchangeable sodium and chloride in normal pregnancy the amount per litre of the total body water is the same as in the non-pregnant female. Although, therefore, there is no evidence of storage of osmotically-active sodium during pregnancy, the total amount is increased and it is natural to assume that this is achieved by an active renal retention. Since the glomerular filtration rate is increased, the process must be one of increased tubular reabsorption. It is however, difficult to prove this from results reported in the literature.

Most of the investigations have taken the form of balance studies without any specific test of the ability of the kidney to handle sodium. In addition they have been concerned with a comparison of normal and pre-eclamptic pregnancies, and provide no base-line for non-pregnant patients. One of the few communications which does give figures for non-pregnant as well as pregnant subjects is that of Smith, Hendrick and Miller (1957). With the same diet non-pregnant subjects excreted 174 to $218 \mathrm{mEq}$. of sodium in 24 hours whereas normal pregnant individuals only excreted $135 \mathrm{mEq}$. We have observed similar results in patients under what may be termed basal conditions. The patients are maintained on a standard diet of known sodium intake. On the day prior to the test no fluids are allowed from 7 p.m. At 7 a.m. in the morning the bladder is emptied and this urine is discarded. For the next three hours the urine is collected and the sodium content measured. Under these conditions it is found that the patient in the last trimester of pregnancy only excretes $80 \%$ of the total found in the urine of the non-pregnant subject. If these patients are then subjected to a loading test by injecting $10 \mathrm{~g}$. of salt intravenously and collecting the urine for the following three hours, the comparative result is the same. Under these conditions the nonpregnant subject will excrete $58 \mathrm{mEq}$. of sodium compared to the $48 \mathrm{mEq}$. by the normal pregnant patient. The difference is even more marked if these tests are carried out on patients during the first two trimesters of pregnancy. This is also apparent from the results of a careful study made by Thomson and Pommerenke (1939) on a 28 year-old primigravid patient whose pregnancy was entirely normal. Estimates of sodium metabolism were made at the fourth month of gestation and again in the eighth and ninth months. During the fourth month the average daily retention of sodium was found to be 19.3 $\mathrm{mEq}$. with an intake of $158 \mathrm{mEq}$. In the eighth and ninth months the average retention had declined to 11.6 and $13.2 \mathrm{mEq}$. respectively. This study was very carefully carried out, attention being paid to details such as the limitation of exertion in order to avoid sweating and thus 
prevent excessive loss of sodium chloride in this manner.

It would appear, therefore, that during normal pregnancy the renal tubular cells have an increased avidity for the reabsorption of sodium. The mechanism is at present unknown but some tentative suggestions may be made. Sodium is reabsorbed from the tubule at four levels at least. According to Windhager, Whittenbury, Oken, Schatzmann and Solomon (1959) approximately 80 to $85 \%$ of the sodium is reabsorbed in the first convoluted tubule. The factors controlling this process are at present unknown. A further proportion of the sodium is reabsorbed in the ascending loop of Henle. This is the basis of the counter-current mechanism. (Gottschalk and Mylle, 1959). In the distal convoluted tubule sodium is exchanged for potassium, which is excreted. This mechanism is probably mediated through the action of aldosterone (Berliner, Kennedy and Orloff, I95I). Finally sodium is reabsorbed in the collecting tubules where it is exchanged for ammonium ions (Ullrich, 1960).

With the increase in GFR a greater volume of fluid is offered to the renal tubule. Under these circumstances proximal reabsorption of sodium tends to be limited, leaving more sodium to be dealt with lower down. Our knowledge of these mechanisms in pregnancy is very limited but from the available reports it appears that there is a great increase in the secretion of aldosterone (Venning, Primrose, Caligaris and Dyrenfurth 1957; Koczorek, Wolff and Beer, 1957; Martin and Mills, 1956; Rinsler and Rigby, 1957; Jones and others, 1959; Kumar, Feltham and Cornell, 1959). The values reported vary to some extent, probably due to different methods of estimation, but the results of Venning and others (1957), Koczorek and others (1957) and Rinsler and Rigby (1957) agree fairly well. According to these writers the output of aldosterone rises from a non-pregnant level of $6 \mu \mathrm{g}$. per 24 hours to values ranging from $16 \mu \mathrm{g}$. to over $100 \mu \mathrm{g}$. per 24 hours according to the stage of pregnancy.

In addition to these reports of increased excretion of aldosterone there is some indirect evidence that this substance is active during pregnancy. Both Rinsler and Rigby (1957) and de Alvarez, Bratvold and Harding (I959) have shown that the ratio of sodium to potassium in the urine is decreased during pregnancy and that this decrease runs parallel with the increase in aldosterone output. Further evidence is supplied by Kumar and others (1959) who have shown that salt restriction in normal pregnancy results in an increased output of aldosterone, and by Barnes and Buckingham (1958) who found that after administering an aldosterone antagonist th output of sodium was greatly increased.

The question arises as to the reason for th\& increased output and activity of aldosterone during. pregnancy. The simple answer is that more: sodium is required for the expansion of the blood? volume, the growth of the fotus and increase of the amniotic fluid. Yet increased aldosterone secretion in the presence of an increased quantity of body sodium and a raised blood volume does seem a paradox. Usually aldosterone secretion i⿱ reduced in these circumstances. In the normat individual it has been demonstrated that the immediate factors stimulating aldosterone secretione are a decrease in whole blood volume or effectivo blood volume (Bartter, Biglieri, Pronove an Delsa, I957), a decrease in extra-cellular flui volume, including blood volume, or a decrease iw total body water (Strauss and Papper, 1959). Sஜ्ठे also the converse, diminution in aldosterone production, may be brought about by increase in extra-cellular fluid or total body water but not b $\vec{b}$ increase in blood volume alone. Luetscher and Lieberman (1958) report that aldosterone secretio $\vec{B}$ is also increased if there is a diminution in the sodium and therefore of the $\mathrm{Na} / \mathrm{K}$ ratio of body fluids. In pregnancy the blood volume is increasedo sodium is retained, and still aldosterone secretion not only is high but goes on increasing throughegut pregnancy. Three mechanisms may be at wotk even with a continually expanding vascular spaç్ there may be a constant deficit of effective blood volume; secondly, there is a drain of sodium an 8 fluid to the conceptus; and lastly, it is clear that it is not an overall volume change which influences aldosterone secretion and sodium metabolism? Pooling of blood in the limbs will increase aldo sterone output and sodium reabsorption. Epsteing (1957) has shown that the same occurs when an arterio-venous fistula is opened. The placentad circulation is in a sense an arterio-venous fistula In addition, it would be reasonable to suppose thaf there are receptors in that area engaged in regula ting maternal blood volume and so maintaining placental blood supply.

Venning, Simpson and Singer (1954) ans others have produced some evidence to sugges $\bar{\hbar}$ that the secretion of other salt-retaining factors in addition to aldosterone, possibly of placentaf origin, are increased in pregnancy. The result of pharmacological tests are interesting in this respect. Drugs, such as chlorothiazide and acetazoleamide which inhibit tubular carbonic anhydrase and thus produce an acidosis have been administered to normal pregnant women. The body, in ridding itself of accumulated acids, uses? sodium as a base and the sodium output is thus? increased. Reports show however (Assali, 1960尽 
Afonso, de Alvarez and Bratvold, 1960) that within a few days the activity of these drugs is lost. There may therefore be an over-riding control of sodium affecting more than one part of the renal tubule in normal pregnancy.

With the available evidence it would appear that the regulation of fluid exchange is achieved by control of the renal excretion of sodium. Water retention is geared to sodium reabsorption, perhaps passively or by interplay between sodium retaining steroids and anti-diuretic hormone.

\section{Compartmental Distribution}

Before proceeding to a discussion of sodium and water metabolism in abnormal pregnancy notice must be taken of certain changes reported to take place towards term which, if confirmed, may alter our outlook on these matters. In addition the question of œdema in normal pregnancy must be considered.

It has been known for some time that the plasma volume tends to fall during the last few weeks of pregnancy (Cope, r958). Associated with this is a fall in the amount of total exchangeable sodium (Davey, O'Sullivan and McClure Brown, 1961). In 1949, however, Caton, Roby, Reid and Gibson, while reporting this same biphasic change in plasma volume, also noted alterations in the relationship between plasma volume and extravascular fluid. They found that while the plasma volume increased progressively until near term, when it fell, the extravascular fluid volume increased right up to term. In early pregnancy the rate of increase of the plasma volume greatly exceeded that of the extravascular fluid, but during the third trimester this ratio was reversed and when the plasma volume fell in the last month of pregnancy the relative size of the extravascular compartment was greatly increased. Confirmation of these findings would be of considerable interest.

\section{Posture and CEdema}

The significance of œdema in pregnancy is not clear, particularly when the patient is otherwise normal. Dexter and Weiss (I94I) reported a $66 \%$ incidence of œdema in normal pregnancy. Even when overt œdema is not present most pregnant women will complain of shoes becoming tight-fitting and wedding rings being impossible to move, particularly at the end of the day. The findings of Janney and Walker (1932) quoted above suggest an explanation, and the process is initiated by means which are largely mechanical. McLennan (1943) has shown that the femoral venous pressure rises from $9 \mathrm{I} \mathrm{mm}$. $\mathrm{H}_{2} \mathrm{O}$ in early pregnancy to $244 \mathrm{~mm}$. in late pregnancy. These observations were made with the patient supine.
Previously, Rona (1935) had noted that with the patient standing the venous pressure varied from 792 to $1230 \mathrm{~mm}$. $\mathrm{H}_{2} \mathrm{O}$. The maximum pressure noted by McLennan is not far short of the osmotic pressure of the plasma proteins in pregnancy, and the figures quoted by Rona are far in excess. In addition Payling Wright, Osborne and Edmonds (1950) found that during pregnancy there is a progressive slowing of venous flow in the lower limbs as pregnancy advanced, and McCausland, Hyman, Winsor and Trotter (I96I) have demonstrated that there is a $150 \%$ increase in venous distensibility during pregnancy.

These changes alone would lead to retention of fluid in the limbs, but alterations in renal function take place which, under certain circumstances, would tend to make the fluid retention more or less permanent. Barger, Liebowitz and Muldowney (1959) dealing with non-pregnant patients have found that in the erect position sympathetic activity is increased and the rate of sodium and water excretion is 25 to $50 \%$ lower than that found when the patient is reclining. Assali, Dignam and Dasgupta (1959) report similar findings in pregnancy. In addition they showed that when the patient was erect there was a fall in the GFR and RPF. The aldosterone output rose markedly. The sequence of events would seem to be that fluid is trapped in the lower limbs and leaks into the interstitial tissues. The circulating volume is thereby reduced and aldosterone secretion is stimulated. This, along with the reduction in GFR and RPF results in retention of sodium and water in order to restore the blood volume. With most normal women the process is reversed on retiring to bed. The venous pressure is relieved, and as Theobald and Verney (1935) reported, the volume of night urine comes to equal that passed during the day. In some women, however, the process is more active, the fluid accumulates in the tissue spaces and the body may ignore it. This is particularly apt to happen if the patient is kept in the supine position. We have recently observed something of this kind in a patient admitted to hospital with odema but no hypertension or albuminuria. Given a waterloading test she only managed to pass $24 \%$ in the supine position. Repeating the test the following day with the patient on her side resulted in an output of $112 \%$. Her œdema improved quickly with postural treatment of this kind.

Even in non-œdematous patients we have noted that, although they will excrete $100 \%$ or more of a water load while lying on their sides, the percentage output falls to around $50 \%$ when in the dorsal position and if made to stand or move about gently there is a further decrease to $30 \%$ or less.

The importance of this type of œdema in the 
limbs cannot be over-emphasized if a proper appreciation of pre-eclampsia is ever to be attained. Many of the conflicting results reported in studies of renal function may well be due to this mechanism.

\section{Pre-eclampsia}

Edema in pre-eclampsia tends to have a general distribution, although always more marked in the limbs and confined to that site in the early stage.

For long, problems of methodology have bedevilled the investigation of renal function and œdema in pre-eclampsia. Many of these problems have been overcome in recent years and we are now able to make a tentative evaluation although much remains to be done before the mechanisms are fully understood.

Clinically we are faced with two facts, albuminuria and oliguria in severe cases. The one argues for increased permeability of the glomerulus, the other for reduced permeability or increased tubular activity.

All investigators are of the opinion that the inulin clearance rate, which is normally supposed to measure GFR, is reduced in pre-eclampsia (Corcoran and Page, I94I; Dill, Isenhour, Cadden and Schaffer, 1942; Wellen, Welsh and Taylor, 1942; de Alvarez, 1950). The values quoted vary, but on average there is a fall from around $120 \mathrm{ml} . / \mathrm{min}$. in the non-pregnant state to $85-90 \mathrm{ml} . / \mathrm{min}$. in pre-eclampsia. Our own findings are similar. The results have been interpreted in several ways. For instance, Corcoran and Page (I94I), from a consideration of histological findings, came to the conclusion that the glomerular membrane was less permeable in pre-eclampsia, but there are a number of arguments against this. For instance, the clinical finding of albuminuria might indicate increased permeability. In addition, Wellen, Welsh and Taylor (1942) compared the excretion of inulin with that of mannitol and sorbitol, both very much smaller molecules. In all three cases the clearance rates were identical. It is difficult to conceive that there is any hindrance to the passage of inulin in these circumstances and one must conclude that the clearance of this substance is a true measure of GFR. The view has also been put forward that the reduced filtration is due to spasm of the afferent arteriole, which would have to be of considerable magnitude in view of the hypertension. Again the pallor of the kidney at postmortem in fatal cases of eclampsia lends some support to this argument. Unfortunately, investigations of renal blood flow do not support this idea of renal ischæmia. On the contrary all of the authors quoted above have found that the effective renal blood flow is either normal $\frac{\overrightarrow{0}}{\Phi}$ r increased, and the kidney would therefore appear to be slightly hyperæmic.

It still remains to resolve the problem of reduced filtration in the presence of hypertension, and albuminuria. The filtration rate is the resultasht of two main forces, the hydrostatic pressure in the glomerulus and the osmotic pressure of the bloog. The pressure within the glomerulus is its gif regulated by two factors, the pressure at the afferent end of the circulation and the tone of the efferent vessel. In pre-eclampsia the blood pressure is increased, the plasma proteins are diminished and one might therefore expect an increased filtration rate. One is forced to conclude, in the absence of any direct evidence of intense afferent spasm, that the reduced GFR is the result of a decreased hydrostatic pressure with the glomerulus achieved by relaxation of the efferent vessel. This has nothing to do wid permeability, for the capillaries of the glomeruluis might still leak protein although the filtration rate of water is reduced. This is an attractive hypothess for if true it assures an adequate blood supply to the kidney, protects the glomerulus to a great extent from damage by high blood pressure and allows very effective reabsorption from ot reduced filtrate which may be necessary.

Albuminuria remains a vexed question, butaits to be noted that the amount of protein passe the kidney varies not only from day to day bot from hour to hour during any one day. Thereăs no doubt that arteriolar and glomerular damage does occur in the most severe cases and it seergis likely that this is related to the high blood pressume (Govan, I96I). Pre-eclampsia is not a staic condition and it seems to me possible that in the early stages of the disease the hæmodynamic changes may not be sufficient to protect the glomerulus at all times. In the late stages it is ri belief that the picture in most cases is dominated by the rising blood pressure and in these circurnstances spasm of the afferent arteriole may play ${ }_{a}$ greater part in the pathology of the disease.

In addition to finding a normal or increased renal blood flow Wellen, Welsh and Taylor (1942:) and others have reported that the tubular excretofy mass is normal, indicating that there is no reductipn in tubular activity.

In summary, therefore, it would appear that apart from a moderate reduction in GFR the functional capacity of the kidney in toxæmia $\stackrel{0}{\text { s }}$ normal. This does not mean that the renal function is qualitatively the same as in normal pregnancy and it remains to relate if possible the urinary findings with what is known of water afd electrolyte balance in pre-eclampsia. 


\section{Volume Control}

It has always been assumed in view of the accompanying œdema that water metabolism is upset in pre-eclampsia and for the past 30-40 years this has been linked with changes in sodium metabolism (Dieckmann, 1935). It is difficult to decide which factor, water or sodium, is the more important, and up to the present, impossible to determine whether these changes are of primary importance in the etiology of pre-eclampsia or merely secondary.

Recent work with ' heavy water' indicates that there tend to be changes in total body water. McCartney, Pottinger and Harrod (1959) found a rise in total water from $78.9 \%$ of the lean body mass in normal pregnancy at 37 to 39 weeks to $81.3 \%$ in pre-eclampsia in a pregnancy of the same duration. MacGillivray (1960) related his figures to the total body weight and showed that in mild pre-eclampsia there was a slight but not significant increase in total body water. In severe pre-eclampsia the increase was greater but still not statistically significant. Plentl and Gray (1959) on the other hand found little difference between normal and pre-eclamptic patients.

The difference in these reported views may well be due to variation in clinical material, such as the stage of the disease, and obesity of the patient. There is a fallacy, as MacGillivray has pointed out, in relating body water to body weight since it is impossible to determine the proportion of the weight which is fat. Chesley and Chesley (1943) showed that the amount of water, as measured by the thiocyanate method, may actually increase although the subject is losing weight. Clinically the disease is usually characterized by œdema, gain in weight and oliguria, therefore it seems reasonable to assume that the amount of body fluid is increased.

The occurrence of oliguria would suggest that the retention of fluid is of renal origin and there is some evidence to suggest that this may be so. Dieckmann (I935) and others have reported that there is a delay in excreting water. Our own studies support this idea. As noted above, a normal pregnant woman, will, when given a water-loading test, excrete at least $100 \%$ of the test dose in 3 hours provided she lies on her side. The same test carried out on a pre-eclamptic patient, with hypertension, albuminuria and œdema yields very different results. As in normal pregnancy, the output of water is reduced, frequently to $20 \%$, when supine but repeating the test with the patient lying on the side may not increase the return to more than $50 \%$.

This reduction in fluid output might be attributed to the fall in GFR but the decrease reported in the latter is insufficient to account for water retention. The alternative is a specific reabsorption of water by the tubules, which would rather suggest anti-diuretic hormone $(\mathrm{ADH})$ activity. This has long been a matter for contention among investigators. Anselmino, Hoffman and Kennedy (1932) were among the first to report an increase of posterior pituitary substance in pre-eclampsia. Indirect support for this idea is found in the work of Dieckmann and Michel (1937) who showed that pituitrin caused a rise in both systolic and diastolic pressures in pre-eclamptic patients. De Valera and Kellar (1938) also demonstrated that pre-eclamptic subjects were more sensitive to pitressin than normal. It has been shown that the serum of normal pregnant women contains an enzyme which inactivates posterior pituitary hormone in vitro (Barnes and Sawyer, I960) and this enzyme is said to be diminished or absent in pre-eclampsia (Hawker, 1956). Assali, Dignam and Longo (I960) claim that whereas the GFR and RPF are not altered by pitressin in the non-pregnant they are diminished by this hormone in pregnancy. They could find no evidence for inactivation of the hormone in vivo. The controversy over posterior pituitary hormone has continued over the past two decades with an almost equal amount of evidence for and against its activity in this disease. In 1953, Arneil and Wilson reported the discovery of a polypeptide, isolated by chromatographic methods, in the urine of patients suffering from oliguria due to renal disease. This polypeptide appeared to have the same chemical composition as ADH. Paterson (1954) working in this department and using this technique, found the same substance present in the urine of preeclamptic and eclamptic patients. A further study (Paterson, 1960) demonstrated its presence in both plasma and urine, and a relationship between its occurrence and the presence of œdema. In this latter communication it is to be noted that in seven out of 86 cases of pre-eclampsia no polypeptide was found in the urine and these patients had only traces of œdema. This of itself tends to make one question the primary position of $\mathrm{ADH}$ in the etiology of pre-eclampsia. In addition, if $\mathrm{ADH}$ were operative from the beginning of the process any increase in available water would be by addition to the body stores and one would expect a gain in weight. Chesley and Chesley (I943) have shown that available water, measured by the thiocyanate method, is increased before any gain in weight is registered in patients who become pre-eclamptic. In other words a redistribution of fluid takes place prior to the onset of typical signs. If this is true then it is doubtful if posterior pituitary substance plays a part in the 
genesis of the syndrome, although it may be of importance in the established disease.

\section{Sodium Metabolism}

Controversy has raged in a similar fashion in the field of sodium metabolism. The number of communications is vast. In the early years most of them dealt with balance studies which purported to demonstrate retention of salt in pre-eclampsia (Taylor, Warner and Welsh, 1939). Similarly, Dieckmann, Smitter, Horner, Pottinger, Rynkiewicz and Lundquist (I95I) reported that the oral administration of salt increased the severity of toxæmic symptoms in approximately $30 \%$ of pre-eclamptic patients. It is to be noted that in these patients there was apparently no restriction of fluid intake. Intravenous injections of large amounts of sodium chloride (Dieckmann, Pottinger and Rynkiewicz, I952) produced marked increases in weight, œdema, hypertension and albuminuria.

It has been accepted for many years that the urine of pre-eclamptic patients contains less sodium chloride than that of normal subjects, although Chesley (1939) was inclined to believe that this might be the consequence of a salt-free diet. Dieckmann, Pottinger and Rynkiewicz (1952) showed that after a sodium chloride load pre-eclamptic patients only excreted $50 \%$ of the output of normal pregnant women. This was confirmed by Willson, Williams and Hayashi (1957). Using somewhat similar methods Halmágyi and Zelenka (1949) and Govan and MacGillivray (1954) reported similar findings and suggested that they were due to active tubular reabsorption of sodium. Subsequently, Chesley, Valenti and Rein (1958) repeated this work and carried out inulin clearances simultaneously with the infusion of sodium chloride. They found that although both fluid and sodium outputs were augmented, the increase in sodium output did not run parallel with the rise in GFR indicating that tubular reabsorption of sodium occurred. Indirect evidence of tubular activity is found in the results of hydrochlorothiazide therapy. Assali (I960) reported that the increased output of sodium was achieved without altering the GFR or RPF. It would appear then that the function of the renal tubule is changed as in normal pregnancy but possibly to a greater degree.

This result is peculiar in view of recent studies of aldosterone excretion in this disease. Martin and Mills (1956) reported that the amounts excreted in pre-eclampsia were within the normal range for pregnancy. On the other hand Rinsler and Rigby (1957), Koczorek, Wolff and Beer (1957) and Kumar, Feltham and Gornall (1959) have all found values lower than normal in pre-eclampsia.
This seems at odds both with an increased refig] avidity for sodium and with the findings relationg to blood volume. As long ago as 1918 Freis and Kenny pointed out that the blood volume is law in pre-eclampsia. Additional evidence wâns supplied by study of hæmatocrit readings (Skajàa, 1929; Crawford, 1940; Botella-Llusia and Arran, 1941). Recently it has been confirmed using mowe modern methods by Rottger (1954) and Mac-Gillivray (1960). It will be remembered that the main mechanisms in stimulating aldosteroge secretion are a change in sodium/potassium ratio or changes in body fluid volumes, especially effective blood volume. One might conclude that the vascular system is well-filled in toxæmia although the blood volume is small. Although aldosterone output may be low compared wh normal pregnancy it is still, according to Koczord and others (1957) well above the non-pregnagyt range, and could be responsible for increased renal tubular absorption of sodium. Nevertheles Barnes and Buckingham (1958) found thigt anti-aldosterone substances had no influence en sodium output in pre-eclampsia.

Whatever the explanation of th sse findings may be, there is some doubt despite the increased reabsorptive capacity of the renal tubule r sodium, whether there is a true retention $\vec{g} f$ sodium in pre-eclampsia. Recent work ofith radiosodium has yielded conflicting restils. McCartney, Pottinger and Harrod (1959) fọ̈d a marked increase of exchangeable sodium in pre-eclamptic patients. Plentl and Gray (1958) have reported similar findings. MacGillivray and Buchanan (1958) however, found the value total exchangeable sodium in pre-eclampsia to $\overline{\mathrm{g}} \mathrm{e}$ similar to that for normal pregnancy. Later MacGillivray (1960) by estimating body water simultaneously with sodium found that the ratio of sodium to body water was less than in normal pregnancy, indicating that water is retainge without sodium chloride. Davey, O'Sullivan a․ㅡㅁ McClure Browne (196r) agree with MacGillivrà, but in addition, by repeated observations on patients throughout pregnancy they haye uncovered some interesting facts. Patients who subsequently developed pre-eclampsia showed on excessive increase in total exchangeable sodium between the sixteenth and twenty-sixth weelNo, but by the time pre-eclampsia became overt the total sodium showed a diminution compared in normals. This may explain to some extent th్ varying results reported by other authors.

\section{Compartmental Distribution}

Even more interesting than measurement $\stackrel{+}{\circ f}$ total sodium and water are the studies of comparemental distribution of these substances. Rosse $\vec{g}-$ 
beck (I93I) found, on analyses of eclamptic tissues that the sodium content was raised and the potassium diminished. Parviainen, Soiva and Ehrnrooth (1950) have made similar claims. These findings, however, may not be of etiological significance. Post-mortem findings represent terminal changes and histologically there is evidence of massive effusion of blood constituents into the tissues which would upset the chemical state in these cases (Govan, 1961). Nevertheless, Mukherjee and Govan (1950) and Tatum (1954) have both found the concentration of sodium to be higher in œdema fluid than in serum. On the other hand MacGillivray (I960) reported less sodium per litre of body water than normal. This refers to total body water and does not necessarily invalidate a compartmental distribution of sodium. There also seems to be a compartmental distribution of water. Reference has been made already to the low blood volume in these cases. It seems very doubtful if this lowering of blood volume can be the result of vaso-constriction. MacGillivray's (I960) results with thiocyanate, bromine and sodium indicate that the extracellular fluid is the same as in normal pregnancy. Since the total body water may be somewhat greater than in normal pregnancy this suggests that fluid is retained within cells, whereas Dieckmann (I94I) had the view that there was a shift of fluid from the cells to the extracellular space, an opinion also held by McPhail (1939). Chesley and Chesley (1943) found that prior to the appearance of the classical triad of pre-eclampsia a gain in extra-cellular water was recorded without a gain in weight, again suggesting a movement from intra-cellular to extra-cellular fluid. These reports are interesting when one recalls that Caton and others (1949) have found evidence for somewhat similar changes in the last month of normal pregnancy. The changes occurring at this period of normal pregnancy would repay investigation and might well help to explain the complicated and apparently paradoxical volume changes in pre-eclampsia.

Although these changes in fluid volume and electrolyte concentration occur one must assume that the isotonicity of the body fluids is maintained and that, as in the normal, this is the main reason for changes in renal function. In this respect it is interesting to glance at the results of therapy involving manipulation of fluid and salt. Turner and Fair (1953) subject their pre-eclamptic patients to hydration therapy, involving the ingestion of almost $6,000 \mathrm{ml}$. of water daily. A low calorie diet containing $0.6 \mathrm{~g}$. sodium chloride is given. This results in a water diuresis, but the excretion of sodium is diminished. First of all, these results indicate that the absorption of water is normal, that the kidneys, in view of the diuresis are essentially normal, and that the centres for $\mathrm{ADH}$ control are sensitive and respond to a water load. With regard to the absence of a sodium diuresis, this is to be expected. Its retention is an indication of the body's attempt to maintain isotonicity, and of the fact that the kidney is carrying out its normal function in this respect. Similarly, with a salt-free diet, sodium disappears from the urine although a mild water diuresis may occur. Again the same process is at work. With a high-salt diet (de Alvarez, 1950) the excretion of sodium rises, but oliguria tends to occur, so that some of the salt is retained in isotonic solution and œdema will increase. Tatum (1955) found that the administration of various solutions to pregnant women produced a net gain in body water provided the solutions were isotonic. The changes were more marked in pre-eclamptic subjects.

It is at this point one comes to a full stop. Further speculation can only be of a very general nature. Edema in the vast majority of cases is not markedly progressive. It is as if the fluid, having been retained for some purpose and that purpose being attained, the body ignores it. One gains the impression that these powers of the kidney to reabsorb sodium and water are largely potential, to be brought into operation when there is a threat to the isotonicity and electrolyte balance of the body fluids, as if the kidney is doing its best to maintain normal conditions in face of changes which are extra-renal. There seems to be a metabolic instability in preeclampsia and the co-ordination of salt and water metabolism and volume control is easily upset. This is implied in reports of hyponatræmia with continuing œdema following treatment with chlorothiazide (Miller, I960). The apparent compartmental changes, if proved to exist, would tend to indicate an underlying fault in cellular metabolism. I have not considered the position of the plasma proteins in relation to œdema. Quite apart from the physical effect of their marked diminution in pre-eclampsia which must tend to create œdema, changes occur in the relative and absolute proportions of the various proteins, which probably indicate alterations in metabolism. It is known that peculiar changes occur in carbohydrate (Govan, Mukherjee, Hewitt and Harper, I95I) and nitrogen metabolism (Mukherjee and Govan, 195I) and that the glycogen stores of the liver are depleted (Mukherjee 1952).

Equally, I have not touched upon the possibility of altered adreno-cortical activity, as distinct from aldosterone, in relation to œedema. Adrenocortical extracts are said to be diuretic and according to most observers the production of corticoids 
is diminished in pre-eclampsia. A fact which may be relevant in this respect is that $I$ have found the adrenals to be smaller than normal in fatal cases of eclampsia. It is interesting to note that a somewhat comparable situation in general medicine is met with in certain forms of cardiac failure. In these cases there is odema with retention of large amounts of sodium but an even greater retention of water (Strauss and Papper, 1959). It has been suggested that there may be an element of adrenal failure in these patients.
Before a final assessment of cedema in pre eclampsia can be made further information on the early changes prior to the onset of symptoms an signs is necessary. The factors involving volume control, even in late normal pregnancy, require: investigation, and in all tests care will have to b) taken that the methods of the investigator such as simple change in the patient's posture do nof

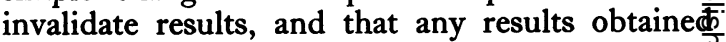
are not related to prior manipulation of salt an water in the diet.

\section{REFERENCES}

Adams, J. Q. (1954): Cardiovascular Physiology in Norman Pregnancy: Studies with the Dye Dilution Techniqued Amer. Y. Obstet. Gynec., 67, 74I.

Afonso, J. F., DE Alvarez, R. R., and Bratvold, G. E. (1960): Natriuresis and Vascular Tone in Toxæmia of Prege nancy, Ibid., 80, 747 .

Albers, H. (1 939): 'Normale und Pathologische Physiologie im Wasserhaushalt der Schwangeren'. Leipzig: Thieme्छे

Anselmino, K. J., Hoffman, F., and W. P. KenNedy (1932): The Relation of Hyperfunction of the Posterior Lobe o₫ the Hypophysis to Eclampsia and Nephropathy of Pregnancy, Edinb. med. F., 39, 376.

ArneIL, G. C., and Wilson, H. E. C. (1953): Isolation of Pituitary Antidiuretic Peptide and Similar Urinary Peptideo by Paper Chromatography, Lancet, i, 568.

Assali, N. S. (1960): Renal Effects of Hydrochlorothiazide in Normal and Toxæmic Pregnancy, Clin. Pharmacol

- Therap., I, 48 . Jignam, W. J., and Dasgupta, K. (1959): Effects of Venous Pooling on Renal Hemodynamics and Water? Electrolyte and Aldosterone Excretion During Normal Pregnancy, F. Lab. clin. Med., 54, 394.

,-- and LoNGo, L. (1960): Effects of Anti-diuretic Hormone on Renal Hemodynamics and Water and Electrolyte Excretion Near Term and Post-partum, F. clin. Endocr., 20, 581.

Aubert, F., Charvet, F., and CreYsser, R. (1955): Clearance Tests in Normal Pregnancy, Rev. Lyon. Med., 4, 467

BALDES, E., and Smirk, F. (r934): Effect of Water Drinking, Mineral Starvation and Salt Administration on TQtaf Osmotic Pressure of Blood in Man, Chiefly in Relation to Problems of Water Absorption and Water Diuresiș

F. Physiol., 82, 62.
BARGER, A. C., LiEBowitz, M. R., and Muldowney, F. P. (1959): The Role of the Kidney in the Homeostatic Adjiste ments of Congestive Cardiac Failure, $\mathcal{~}$. chron. Dis., 9, $57 \mathrm{I}$.

Barnes, A. C., and BuCKInghaM, J. C. (I958): Electrolyte Balance Studies with the Antihormones, Amer. F. Obsteto Gynec., 76, 955.

- and SAWYER, J. B. (1960): Measurements of Vasopressinase in Maternal and Cord Blood, Ibid., 79, 1053.

BartTer, F. C., Biglieri, E. G., Pronove, P., and Delsa, C. S. (1957): 'The Effect of Change in Intravascular Volume on Aldosterone Excretion in Man'. International Symposium on Aldosterone, Geneva. London: J. \& $A_{\overrightarrow{0}}$ Churchill.

Berliner, R. W., Kennedy, T. J., and OrLoff, J. (195I): Relationship Between Acidification of Urine and Potassium Metabolism: Effect of Carbonic Anhydrase Inhibition on Potassium Excretion, Amer. Y. Med., II, 274.

Botella-Llusia, J., and ArRanz, P. (1941): Studien über den Wasserhaushalt in der Schwangerschaft und in de? Schwangerschafts Toxikose, Klin. Wschr., 20, 837.

Bucht, H., and WERKö, L. (1953): Glomerular Filtration Rate and Renal Blood Flow in Hypertensive Toxæmia o o Pregnancy, F. Obstet. Gynac. Brit. Emp., 60, 157.

Caton, W. L., Roby, C. C., Reid, D. E., and Gibson, J. G. (1949): Plasma Volume and Extra-vascular Fluid Volume During Pregnancy and the Puerperium, Amer. $\mathcal{F}$. Obstet. Gynec., 57, $47 \mathrm{I}$.

ChesLeY, L. C. (I939): Certain Laboratory Findings and Interpretations in Eclampsia, Ibid., 38, 430.

- (1943): Study of Extracellular Water Changes in Pregnancy, Surg. Gynec. Obstet., 76, 589.

- (1944): Weight Changes and Water Balance in Normal and Toxic Pregnancy, Amer. Y. Obstet. Gynec., 48, 565. , and Chesley, E. R. (1943): An Analysis of Some Factors Associated with the Development of Pre-eclampsia Ibid., 45, 748 .

-, VALENTI, C., and Rein, H. (1958): Excretion of Sodium Loads by Non-pregnant and Pregnant Normal, Hyper至. tensive and Pre-eclamptic Women, Metabolism, 7, 575.

, and Uichanco, L. (1959): Alterations in Body Fluid Compartments and Exchangeable Sodium in the Early Puerperium, Amer. $\mathscr{F}$. Obstet. Gynec., 77, 1054.

Coons, C. M., Coons, R. R., and Schiefilbusch, A. T. (1934): The Acid Base Balance of the Minerals Retained During

Pregnancy, F. biol. Chem., 104, 757.
Cope, I. (1958): Plasma and Blood Volume Changes in Late and Prolonged Pregnancy, f. Obstet. Gynac. Brit. Emp. 잔 $65,877$.

Corcoran, A. C., and Page, I. H. (1941): Renal Function in Late Toxæmia of Pregnancy, Amer. F. med. Sci., 201, 38 年

Crawford, M. D. (1940): Changes in Blood Concentration in Normal and Toxæmic Pregnancy, F. Obstet. Gyneaas Brit. Emp., 47, 63.

Davey, D. A., O'Sullivan, W. J., and McClure Browne, J. C. (196r): Total Exchangeable Sodium in Normal Preg nancy and in Pre-eclampsia, Lancet, i, 519.

DE Alvarez, R. R. (1950): Glomerular Filtration Rates, Renal Plasma Flow and Sodium and Water Excretion in Preg呙 nancy Toxæmia, Amer. F. Obstet. Gynec., 60, I05I 
Bratvold, G. E., and Harding, G. T. (1959): The Renal Handling of Sodium and Water in Normal and Toxemic Pregnancy, Ibid., 78, 375 .

DE Valera, E., and Kellar, R. J. (1938): On the Effects of Intravenous Vasopressin on Toxæmias of Pregnancy, F. Obstet. Gynac. Brit. Emp., 45, 815 .

Dexter, L., and Weiss, S. (1941): 'Pre-eclamptic and Eclamptic Toxemia of Pregnancy'. Boston: Little, Brown.

DieckmanN, W. J. (1935): Renal Function in the Toxemias of Pregnancy, Amer. F. Obstet. Gynec., 29, 472.

- (1941a) 'The Toxemias of Pregnancy'. St. Louis: C. V. Mosby. (194Ib): Edema in Pre-eclampsia and Eclampsia, Amer. F. Obstet. Gynec., 41, r.

, and MicheL, H. L. (1937): Vascular and Renal Effects of Posterior Pituitary Extracts in Pregnant Women, Ibid., 33, $13 \mathrm{I}$.

- Pottinger, R. E., and Rynkiewicz, L. M. (1952): The Etiology of Pre-eclampsia-Eclampsia, Ibid., 63, 783. , Smitter, R. C., Horner, E. N., Pottinger, R. E., Rynkiewicz, L., and Lundouist, R. (I95I): The Effect of Oral Ingestion of Sodium Chloride and Sodium Bicarbonate by Patients with Toxemia of Pregnancy, Ibid., 6r, I100.

- and Wegner, C. R. (I934): Blood in Normal Pregnancy: Blood and Plasma Volumes, Arch. intern. Med., 53, 7I.

Dill, L. V., Isenhour, C. E., CADDEN, J. F., and Schaffer, N. K. (1942): Glomerular Filtration and Renal Blood Flow in the Toxemias of Pregnancy, Amer. F. Obstet. Gynec., 43, 32.

Epstein, F. H. (1957): 'Renal Excretion of Sodium and the Concept of a Volume Receptor'. Essays in Metabolism. Boston: Little, Brown.

Freis, E. D., and KenNy, J. F. (1948): Plasma Volume, Total Circulating Protein and Available Fluid Abnormalities in Pre-eclampsia and Eclampsia, F. clin. Invest., 27, 283.

GotTschalk, C. W., and Mylle, M. (1949): Micropuncture Study of the Mammalian Concentrating Mechanism: Evidence for the Counter-current Hypothesis, Amer. F. Physiol., 196, 927.

Govan, A. D. T. (1961): The Pathogenesis of Eclamptic Lesions, Schweiz. Z. Path. (in press). , and MacGillivray, I. (1954): Renal Function and Chloride Metabolism in Pre-eclamptic Toxæmia, f. Obstet. Gynac. Brit. Emp., 6r, 49 I.

- Mukherjee, C. L., Hewitt, J., and Harper, W. F. (1951): Studies of Carbohydrate Metabolism in Pregnancy Hypertension, Ibid., 58, 788 .

Halmagyi, D., and Zelenka, L. (1949): Tubular Reabsortion of Chlorides in Eclampsia, Gynacologia (Basel), 128, 248.

Hamilton, H. F. H. (1949): The Cardiac Output in Normal Pregnancy, F. Obstet. Gynac. Brit. Emp., 56, 548.

Hawker, R. W. (1956): Inactivation of Anti-diuretic Hormone and Oxytocin During Pregnancy, Quart. F. exp. Physiol., 4I, 30I.

Hummel, F. C., Hunscher, H. A., Bates, M., Bonner, P., and Macy, I. G. (1937): A Consideration of the Nutritive State in the Metabolism of Women During Pregnancy, $\mathcal{F}$. Nutr. 13, 263.

JANNEY, J., and WALKeR, E. (I932): Kidney Function in Pregnancy: Water Diuresis in Normal Pregnancy, $\mathcal{F}$. Amer. med. Ass., 99, 2078.

Jones, K. M., Lloyd-Jones, R., Riondel, A., Tait, J. F., Tait, S. A. S., Bulbrook, R. D., and Greenwood, F. C. (1959): Aldosterone Secretion and Metabolism in Normal Men and Women and in Pregnancy, Acta endocr. (Kbh.), 30, 321 .

Koczorek, Kh. R., Wolff, H. P., and BeER, M. L. (1957): Uber die Aldosteronausscheidung bei Schwangerschaften und bei Schwangerschaften Toxikosen, Klin. Wschr., 35, 497.

Kumar, D., Feltham, L. A. W., and Gornall, A. G. (1959): Aldosterone Excretion and Tissue Electrolytes in Normal Pregnancy and Pre-clampsia, Lancet, i, 54I.

Leutscher, J. A., jr., and Lieberman, H. (1958): Aldosterone, Arch. intern. Med., I02, 314.

McCartney, C. P., Pottinger, R. E., and Harrod, J. P. (1959): Alterations in Body Composition During Pregnancy, Ibid., 77, 1038 .

McCausland, A. M., Hyman, C., Winsor, T., and Trotter, A. D. (i96i): Venous Distensibility During Pregnancy, Ibid., 81, 472.

MacGillivraY, I. (1960): 'Water and Electrolyte Changes in Normal and Pre-eclamptic Pregnancies: Water and Electrolyte Metabolism'. Editors: C. P. Stewart and Th. Strengers, p. 124. Amsterdam: Elsevier Publ. Co. , and Buchanan, T. J. (1958): Total Exchangeable Sodium and Potassium in Non-pregnant Women and in Normal and Pre-eclamptic Pregnancy, Lancet, ii, rogo.

McLennan, C. E. (1943): Antecubital and Femoral Venous Pressure in Normal and Toxemic Pregnancy, Amer. Y. Obstet. Gynec., 45, 568 .

McPhail, F. L. (1939): Water Exchange in Relation to Toxemias of Pregnancy, West. Y. Surg., 47, 306.

MarTin, J. D., and Mills, I. H. (1956): Aldosterone Excretion in Normal and Toxæmic Pregnancies, Brit. med. F., ii, 57 I.

Miller, J. N. (1960): Hyponatræmia: A Complication of the Treatment of the CEdema of Pregnancy, Obstet. Gynec., 16, 587 .

MukherJeE, C. L. (1952): Studies on Carbohydrate Metabolism in Toxæmia of Pregnancy, f. Indian med. Ass., 21, 279. , and Govan, A. D. T. (1950): The Nature of the Tissue Fluid in the Edema of Toxæmia of Pregnancy, $\mathcal{f}$. clin. Path., 3, 274.

- T (I95 I): Nitrogen Metabolism in Hypertensive Toxæmia of Pregnancy, F. Obstet. Gyncec. Brit. Emp., 58, 702.

Mull, J. W., and BILl, A. H. (1945): Alterations in Concentration of Blood During Pregnancy, $\mathcal{~}$. Lab. clin. Med., 30, 458 .

PAGE, E. W. (1957): The Physiology of Edema in Pregnancy, West. F. Surg., 65, 166.

Parviainen, S. Soiva, K., and Ehrnrooth, C. A. (1950): Some Aspects of the Ætiology and Prevention of Eclampsia Studied in the Light of a Severe Case of Pre-eclampsia, with Special Reference to the Sodium, Potassium and Chloride Content of Certain Tissues, Ann. Chir. Gynac. Fenn., 39, I7 I.

Paterson, M. L. (1954): Posterior Pituitary Substance in the Urine of Toxæmic Patients, f. Obstet. Gyncec. Brit. Emp., 6r, 203.

- (1960): The Role of the Posterior Pituiary Anti-diuretic Hormone in Toxæmia of Pregnancy, Ibid., 67, 883. 
Payling Wright, H., Osborn, S. B., and Edmonds, D. G. (1950): Changes in the Rate of Flow of Venous Blood in the Leg During Pregnancy, Measured with Radio-active Sodium, Surg. Gynec. Obstet., 90, 481.

Plentl, A. A., and Gray, M. J. (1959): Total Body Water, Sodium Space and Total Exchangeable Sodium in Normak and Toxemic Pregnant Women, Amer. F. Obstet. Gynec., 78, 472.

RinsleR, M. G., and RIGBY, B. (1957): Function of Aldosterone in the Metabolism of Sodium and Water in Preg-c nancy, Brit. med. F., ii, 966.

RonA, A. (1935): Studien über die Ödembereit chaft in der Schwangerschaft, Z. Geburtsh. Gynak., r12, 62.

RossenBECK, H. (1931): Eklampsie und Ionenhaushalt. Blut und Organanalytische Untersuchungen als Beitrag zur Patho-Biologie der Eklampsie, Arch. Gynak., I45, 33 I.

RotTger, H. (1954): Water Metabolism in Physiological and Toxæmic Pregnancy. II: Water Metabolism in Late음 .Toxæmias, Ibid., 184, 629 .

Sims, E. A. H., and Krantz, K. E. (1959): Renal Hemodynamics in Normal Pregnancy, Amer. F. Obstet. Gynec., $\overrightarrow{\mathbb{D}}$ 77, 459 .

SkajaA, K. (1929): Variations in the Cell Volume of the Blood in Pregnancy Toxæmia and in Labour, Acta obstet.心 gynec. scand., 8, 371 .

Smirk, F. (1933a): Rate of Water Absorption in Man and Relationship of Water Load in Tissues to Diuresis, $\vec{\circ}$ Y. Physiol., 78, 113. (1933b): Effect of Water Drinking on Blood Composition of Human Subjects in Relation to Diuresis, Ibid., $\vec{\omega}$ $78,127$. (1933c): Influence of Posterior Pituitary Hormone on Absorption and Distribution of Water in Man, Ibid. $78,147$.

Smith, R. C., Hendrick, J. W., and Miller, H. R. (1957): Mercurial Diuretics in Toxemia of Pregnancy with Sodiumi. and Potassium Studies, Amer. F. Obstet. Gynec., 73, 784 .

STrauss, M. B., and PAPPER, S. (1959): Sodium and Water Retention in Chronic Congestive Heart Failure, $\mathcal{F}$. chron. Dis., 9, 536 .

Tatum, H. J. (I954): Compartmental Distribution and Shift of Water and Electrolytes in Pre-eclampsia. Part I:ंN Distribution of Electrolytes in the Serum and Edema Fluid, Amer. F. Obstet. Gynec., 67, 1197.

(1955): Compartmental Distribution and Shift of Water and Electrolytes in Pre-eclampsia. Part II: A Com-o parison of the Effects of Isotonic and Hypertonic Solutions of Glucose when Administered to Patients with Preeclampsia, Ibid., 69, 415.

Taylor, H. C., Warner, R. C., and Welsh, C. A. (I939): The Relationship of the Estrogen and other Placental Hor $\frac{D}{9}$ mones to Sodium and Potassium Balance at the End of Pregnancy and in the Puerperium, Ibid., 38, 748.

Theobald, G. W. (1934): Alleged Relation of Hyperfunction of Posterior Lobe of Hypophysis to Eclampsia and Nephropathy of Pregnancy, Clin. Sci., 1, 225. (1946): Discussion on Water Metabolism in Pregnancy, Proc. roy. Soc. Med., 39, 56r.

- and Verney, E. B. (1935): Mechanical Factors which Affect Secretion of Urine in Mammals and Their Ope tions During Pregnancy, Quart. F. Physiol., 25, 341.

Thompson, H. E., jr., and Pommerenke, W. T. (1939): Electrolyte and Nitrogen Metabolism in Pregnancy, f. Nutr I7, 383 .

Turner, H. B., and FAIR, D. (I953): Sodium Excretion in Toxemia of Pregnancy. I: Effects of Hydration Therapyo on Urinary Sodium Output, Obstet. Gynec., 2, 6 r 9.

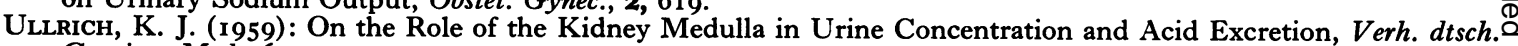
Ges. inn. Med., 65, 242.

Venning, E. H., Primrose, T., Caligaris, L. C. S., and Dyrenfurth, I. (1957): Aldosterone Excretion in Pregnancy, F. clin. Endocr., I7, 473.

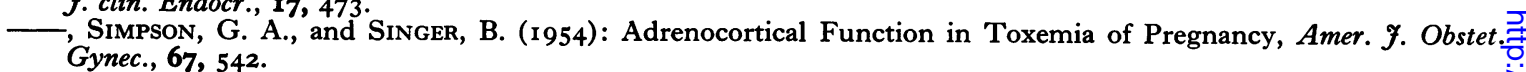

Walker, E., McManus, M., and Janney, J. (1933): Kidney Function in Pregnancy: Effect of Posture on Diuresis, Proc. Soc. exp. Biol. Med., 3I, 392.

Wellen, I., Welsh, C. A., and TAYlor, H. C. (r942): The Filtration Rate, Effective Renal Blood Flow, Tubulari Excretory Mass and Phenol Red Clearance in Specific Toxemia of Pregnancy, $\mathfrak{F}$. clin. Invest., 21, 63.

Willson, J. R., Williams, J. M., jr., and HaYashi, T. T. (ig57): Hypertonic Saline Infusions for the Differential Diagnosis of the Toxemias of Pregnancy, Amer. F. Obstet. Gynec., 73, 30.

Windhager, E. E., Whittenbury, G., Oken, D. E., Schatzmann, H. J., and Solomon, A. K. (I959): Single Proximial Tubules of the Necturus Kidney. III: Dependence of $\mathrm{H}_{2} \mathrm{O}$ Movement on $\mathrm{NaCl}$ Concentration, Amer. $\mathcal{F}$. Physiol., 을 I97, 313 . 